International Journal of

Supply Chain and Logistics

(IJSCL)

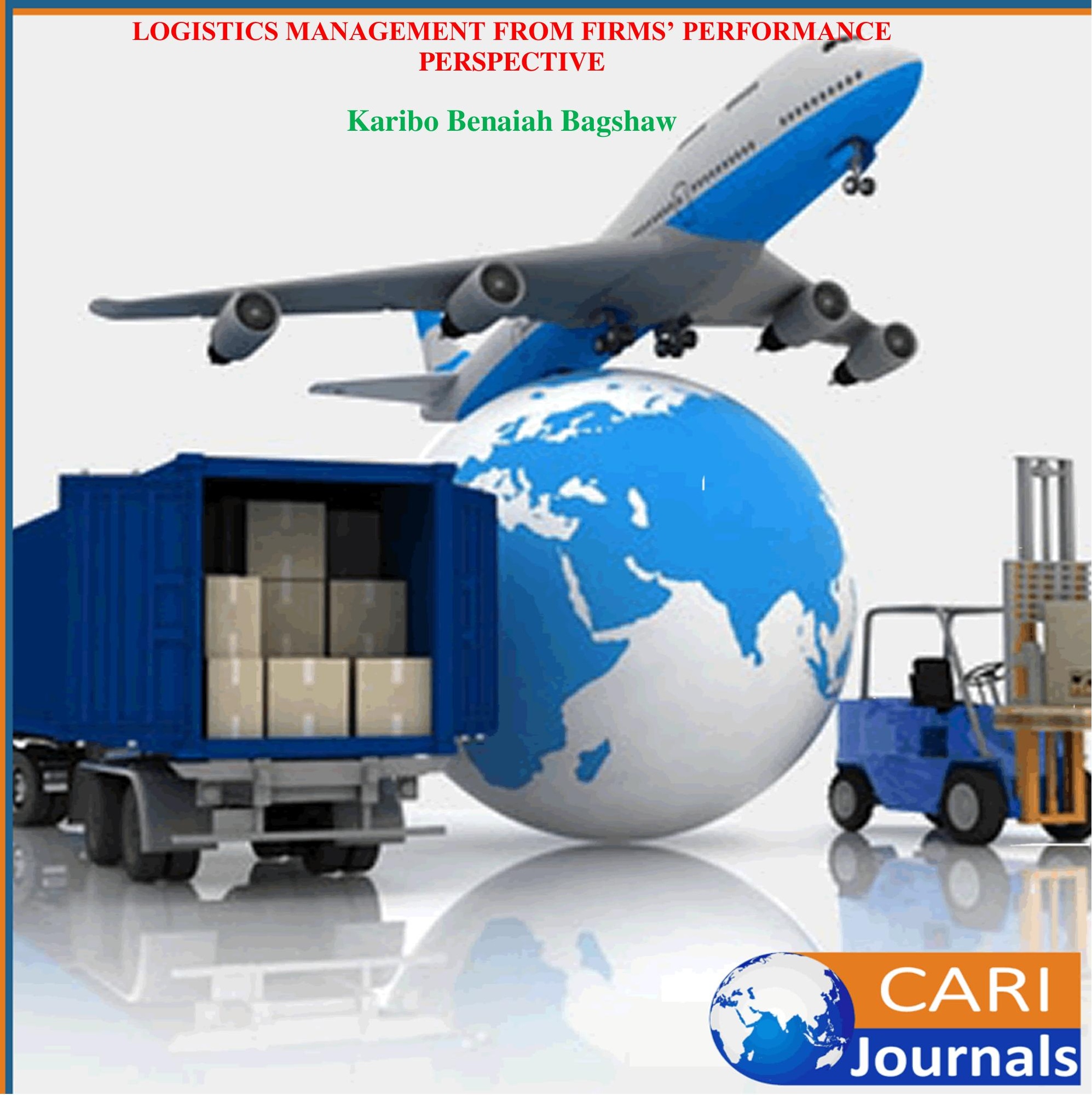




\title{
LOGISTICS MANAGEMENT FROM FIRMS' PERFORMANCE PERSPECTIVE
}

\author{
*Karibo Benaiah Bagshaw \\ Department of Management \\ Rivers State University \\ Port Harcourt, Nigeria \\ Email: bagshaw.karibo@ust.edu.ng
}

ABSTRACT

Purpose: The study was carried out to throw light on how effective logistics management has on on-time delivery and sales growth. Efficient and effective logistics management is viewed and regarded as competitive tool used as a means of increasing performance. This study empirically looked at the relationship between logistics management and performance of 122 selected firms across Rivers State, Nigeria. It focused on logistics management (using the dimension of transportation and physical distribution) on on-time delivery and sales growth.

Methodology: The research framework was examined by empirical analysis of primary data collected through the use of questionnaire; hence the study adopted the research survey method.

Results: The outcome of the analysis revealed that effective transportation and distribution influences on-time delivery and sales growth respectively.

Contributions: Therefore, organizations should establish and maintain standard and vanilla logistics management system, so that the right amount of stock is held and economic order quantity is achieved through proper physical distribution of the product to achieve higher performance. Also, to attain reasonable on time delivery firms in general and managers in particular should be properly equipped with the newest technology in transportation.

Keyword: Logistics Management; Transportation; Physical Distribution; On-time Delivery; Sales Growth.

\subsection{INTRODUCTION}

Globalization is forcing firms to be more careful about customer satisfaction and profit maximization; firms are now using different tools in ensuring that customers especially those that are sensitive to price increase remain loyal to the firm in order to maximize profit. In achieving this, managers are now applying effective and efficient logistics management as a key tool that builds cost and service advantages to the firms (Gebresenbet and Bosona, 2012).

The responsibility of logistics management is to carry products (raw materials, work in progress and finished products inventories) from supply sources to demand destinations, meeting demand on time and providing efficient service delivery to improve organizational performance (Banon and Sanchez, 2002). This therefore means that, the success of any manufacturing firm in Nigeria, points to the ever growing awareness that the firm is enhanced through the even distribution of goods and services, from the point of production to the final consumer (Adedeji, 2005).

Logistics helps to optimize the existing production and distribution processes of firms through proper management techniques for promoting the efficiency and competitiveness of the firm. According to Rui and Luis (2014) the key element in a logistics chain is transportation and distribution system. 
Furthermore, transportation and distribution is a topic of global significance and summary of activities that take place in the logistics systems (Rui and Luis, 2014). Transportation and physical distribution services are important activities which assist in national and global distribution (Stainer, 1997). It enables materials and goods to be moved from a location where they are in excess or surplus to a location where there is demand or shortage or non-existent (Ballou, 1998). It also provide services which link manufacturers to markets and enable individuals to access employment, goods, services and social opportunities. Different modes of transport are used in the transfer of manufactured goods from places of supply or production to areas of demand or consumption (Bamaiyi, 2011; Musa, 2008).

The ability of firms to distribute products effectively has become one of the major challenges facing business organizations, especially when it comes to transporting products, from the production plant to their various customers. The need to transport goods to customers not only imposes direct costs on manufacturers but also affects the on time delivery and sales growth of the firm.

Logistics is an important part of human activity. It forms the basis of all socioeconomic interactions. In many developing countries like Nigeria, lack of transport facilities often hinders economic development. Bad roads, inadequate fleets of vehicles, inadequate trains, overcrowded airplanes and congested ports are common factors in Nigeria that affect logistics management (transportation and distribution channel).

With the entire problem associated with logistics management in terms of transportation and distribution channel, man is faced with the responsibility of getting a solution. Unfortunately, with the technical ability to solve such problems well in place, logistics management is confronted by a transportation and distribution problem that is more complex than ever before (Banon and Sanchez, 2002). Hence the reason for this research work is to ascertain the role of logistics management using the dimension of transportation and physical distribution on the efficiency of business organizations using on time delivery and sales growth in Rivers State.

\subsection{REVEIW OF RELATED LITRATURE}

\subsection{Concept of Logistics Management}

The Council of Logistics Management defined logistics management as the process of planning, implementing and storage of raw materials, in-process inventory, finished goods and related information from point of origin to point of consumption for the purpose of conforming to customer requirements (Kasilingam, 1998). Logistics is the management of the flow of goods between the point of origin and the point of consumption in order to meet customers' requirements. Therefore, logistics represents a collection of activities that ensures the availability of the right products in the right quantity to the right customers at the right time. The resources managed in logistics can include physical items, such as food, materials, animals, equipment, and liquids, as well as abstract items, such as time, information, particles, and energy.

Logistics activities serve as a link between production and consumption and provide a bridge between production and market locations or suppliers separated by distance and time. The main purpose of logistics is to coordinate a bunch of related activities which work together to create a supply chain and provide time and location benefits for customers (Çanci, 2003).

Today, efficient logistics and transportation system are important prerequisites of the development of any economy. In modern competitive environment, it is not enough to offer a product that meet customers' requirements. The way of delivery is very important as precision of product delivery can help businesses operate more efficiently, lower costs and gain new customers which eventually 
lead to higher performance (Balakrishnan, 2009). Also, Fugate, Mentzer, and Stank (2010) observed that logistic management is a strategic vector in companies' organization and influences their performance, in terms of service quality, effectiveness and overall profitability.

\subsection{Physical Distribution}

Distribution of goods and services has been an essential feature of industrial and economic life. Hesse and Rodrigue (2000) observed that distribution is a service that adds value to products by making them available at the right time, in the right place, which provides an interface with the customer.

Physical distribution is a whole process that concern materials and finished product, of physical movement of goods from the manufacturers to intermediaries and finally to the ultimate consumer. There are various routes that products or services use after their production until they are purchased and used by end users. Therefore, distribution channels are all those organizations that a product has to go through between its production and consumption (Kotler and Keller, 2006). Distribution channel management is very critical for the firms when they decide to enter one or more markets. Increasingly, the roles of logistics service firms are included in the decision process for distribution channel, especially when they are a dominant element within the supply chain.

The ability to ensure accurate delivery of a product and raw materials, especially over long distances is vital to the overall operation and success of manufacturing firms (Flowmaster, 2010). Also, Richard (1965) concluded that a highly responsive and reliable physical distribution system facilitates marketing efforts and actually help to generate additional sales volume for firms. More so, it helps to minimize out-of-stock occurrences through more accurate inventory placement and control, hence, sales lost due to being out of stock will be minimized (Richard, 1965). More so, Bovee and Thill (2003) observed that physical distribution is often one of the biggest influences on a firm's ability to successfully deliver products on time and it plays major roles in the performance of manufacturing firms.

\subsection{Transportation}

Generally, transportation is the actual physical movement of people and goods from one place to another (Ahukannah, Ndinaechi, and Arukwu, 2003). It is basically the movement of products from one location to another as it makes its way from the beginning of a supply chain to the customer's hands. Transportation not only ensures movement of people but also goods thus assisting the economy in the growth of trade and commerce (Cooper, Lambert and Pagh, 2013). Transportation plays a connective role among the several steps that result in the conversion of resources into useful goods in the name of the ultimate consumer. It is the planning of all these functions and sub-functions into a system of product movement from supply sources to demand destinations in order to minimize cost and maximize service to the customers that constitutes the concept of business logistics (Fair and Williams, 1981)

The transportation cost includes the means of transportation, corridors, containers, pallets, terminals, labours, and time hence logistics managers must comprehend transport system operation thoroughly (Hesse and Rodrigue, 2000). Transportation system makes goods and products movable and provides timely and regional efficacy to promote value-added under the least cost principle (Yung-Yu, Wen- Long and Michael, 2005). Transport affects the results of logistics activities and influences production and sale (Hesse and Rodrigue, 2000). More so, Yung-Yu, Wen- Long and Michael (2005) opined that transportation is the base of efficiency in logistics management and a good transport system brings benefits not only to service quality but also brings 
about sales growth in the firm. Furthermore, Geraldine and Chikwendu (2013) observed that continuous increase in the cost of transportation due to poor nature of roads, high cost of vehicles and spare parts poses a serious problem to an effective coverage of territories and on time delivery of firm's products.

\subsection{Sales Growth}

The corresponding ratio of a firm performance in either quarterly, half-yearly or yearly basis to measures its performance is known as sales growth and it is achieved by annual addition of previous sales figures derived by a firm compared to the corresponding period of time that exceeds the former year (Nwokah, 2008).

Mohd and Yusuo (2013) posited that key players in industries try to increase their revenue in terms of sales growth and market share. Also, every business organization wants to stay on the top and remain there and for those that are not there they want to get to the top. However, for that to happen businesses has to measure their previous year's performance with current year performance which will help them measure up with competition and improve sales where necessary and increase their profit through sales.

Yung-Yu, Wen- Long and Michael (2005); Nwokah (2008) further noted that the sales growth of a firm can be affected by some controllable or uncontrollable factors like income level, change in taste, technology, quality and ineffective logistics management.

\subsection{On-time delivery}

On time delivery is a path of supply chain efficiency which measures the amount of finish goods or services delivered to customers on time and in full (Masonn and Lalwani, 2004). It helps determine how efficiently firms are meeting their customer's or agreed deadlines (Stock and Lambert, 2001). If the figure is too low or below the benchmark it could be used as a signal that somewhere along the supply chain there are bottlenecks, inefficient or time consuming processes which are not adding value and warrant further investigation or a slower delivery method is being employed (Minner, 2001).

On-time delivery focuses on the delivery service time as a vital metric for evaluating organizational performance (Fawcett and Cooper, 1998). According to Mattsson (2004) on time delivery, together with the aspects of delivery time, delivery flexibility and delivery stability are all aspects of lead time. In order for firms to become closer to their customers and provide improved customers services, they need to be able to deliver goods and services on time (Griffith, Bryce, Omernik, Comstock, Rogers, Harrison, Hatch, and Bezanson, 2004).

\subsection{METHODOLOGY}

This study adopts the quantitative research methodology to empirically assess the relationship between logistics management and performance of firms in Nigeria. The survey research design was adopted with a given sample size selected from 135 firms in Rivers State. In order to test the relationship between the two variables in this study, a research questionnaire was designed to elicit information from managers of the selected firms to determine whether or not logistics management has an influence on the performance of their firms. However, 122 questionnaire were properly filled and returned hence, 122 became the sample size for which the analysis was done. The data was analysed using percentages, means, standard deviation and Pearson Moment Correlation was used to test the relationship between transportation, physical distribution and on time delivery and 
sales growth respectively through the use of Statistical Package for Social Sciences (SPSS) Windows version 22 with a significance level of 0.05 .

\subsection{RESULTS}

This section involves the analyses of the data obtained from the research instrument that was distributed.

\subsection{Item Scores on each of the Variables}

It covers physical distribution, transportation, sales growth and on time delivery, as variables used in the study.

\subsubsection{Item and Scores on Physical Distribution}

Four measurement items A1, A2, A3 and A4, were used to collect data on physical distribution and the response scores presented in Table 1.

Table 1: Item scores on Physical distribution

\begin{tabular}{|l|l|l|l|l|}
\hline & A1 & A2 & A3 & A4 \\
\hline $\mathrm{N} \quad$ Valid & 122 & 122 & 122 & 122 \\
Mean Missing & 0 & 0 & 0 & 0 \\
Median & 4.30 & 4.15 & 4.01 & 4.03 \\
Mode & 4.00 & 4.00 & 4.50 & 4.00 \\
Std. Deviation & 4 & 4 & 5 & 4 \\
Minimum & .462 & .509 & 1.263 & .616 \\
Maximum & 4 & 2 & 1 & 2 \\
Sum & 5 & 5 & 5 & 5 \\
\hline
\end{tabular}

Source: Field Survey Data, 2017.

The data in Table 1 above showed that the respondents agreed on all items on physical distribution with a mean score greater than 4. More than half of the respondents agreed that physical distribution helps to improve the efficiency of the given firm.

\subsubsection{Items Scores on Transportation}

Four measurement items A5, A6, A7 and A8 were employed to collect data on transportation and the response scores presented in Table 2 . 
Table 2: Item scores on Transportation

\begin{tabular}{|c|c|c|c|c|c|}
\hline & & A5 & A6 & A7 & A8 \\
\hline & Valid & 122 & 122 & 122 & 122 \\
\hline & Missing & 0 & 0 & 0 & 0 \\
\hline $\mathrm{Me}$ & & 4.70 & 4.50 & 4.60 & 4.70 \\
\hline $\mathrm{Me}$ & & 5.00 & 4.50 & 5.00 & 5.00 \\
\hline Mc & & 5 & $4^{\mathrm{a}}$ & 5 & 5 \\
\hline Std & tion & .462 & .502 & .492 & .462 \\
\hline $\mathrm{Mi}$ & & 4 & 4 & 4 & 4 \\
\hline $\mathrm{Ma}$ & & 5 & 5 & 5 & 5 \\
\hline $\mathrm{Su}$ & & 573 & 549 & 561 & 573 \\
\hline
\end{tabular}

\section{Source: Field Survey Data, 2017}

The data in Table 2 above showed that the respondents agreed on all items on transportation with a mean score greater than 4. More than half of the respondents agreed that proper transportation of products helps to improve the efficiency of the given firm.

\subsubsection{Item Scores on Sales Growth}

Four measurement items B1, B2, B3 and B4 were used to collect data on sales growth and the response scores presented in Table 3.

Table 3: Item scores on Sales Growth

\begin{tabular}{|c|c|c|c|c|c|}
\hline & & B1 & B2 & B3 & B4 \\
\hline & Valid & 122 & 122 & 122 & 122 \\
\hline & Missing & 0 & 0 & 0 & 0 \\
\hline $\mathrm{Me}$ & & 4.60 & 4.27 & 4.65 & 4.13 \\
\hline $\mathrm{Me}$ & & 5.00 & 4.00 & 5.00 & 4.00 \\
\hline Mc & & 5 & 4 & 5 & 4 \\
\hline Stc & tion & .492 & .499 & .480 & .655 \\
\hline Mi & & 4 & 3 & 4 & 1 \\
\hline $\mathrm{Ma}$ & & 5 & 5 & 5 & 5 \\
\hline Su & & 561 & 521 & 567 & 504 \\
\hline
\end{tabular}

Source: Field Survey Data, 2017.

The data in Table 3 above showed that the respondents agreed on all items on sales growth with a mean score greater than 4 . More than half of the respondents agreed that for a firm to improve its sales growth, the firm should adopt effective and efficient logistics management.

\subsubsection{Items Scores on On-time Delivery}

Four measurement items B5, B6, B7 and B8 were employed to collect data on on-time delivery and the response scores presented in Table 4. 
Table 4: Item scores on On-time Delivery

\begin{tabular}{|c|c|c|c|c|c|}
\hline & & B5 & B6 & B7 & B8 \\
\hline & Valid & 122 & 122 & 122 & 122 \\
\hline & Missing & 0 & 0 & 0 & 0 \\
\hline $\mathrm{Me}$ & & 4.60 & 4.02 & 4.70 & 4.20 \\
\hline $\mathrm{Me}$ & & 5.00 & 4.00 & 5.00 & 4.00 \\
\hline Mo & & 5 & 4 & 5 & 4 \\
\hline & & .492 & .710 & .462 & .602 \\
\hline Mir & & 4 & 3 & 4 & 3 \\
\hline $\mathrm{Ma}$ & & 5 & 5 & 5 & 5 \\
\hline Sun & & 561 & 491 & 573 & 513 \\
\hline
\end{tabular}

Source: Field Survey Data, 2017.

The data in Table 4 above showed that the respondents agreed on all items on sales growth with a mean score greater than 4. More than half of the respondents agreed that for a firm to delivers product on time appropriate logistics management should be put in place.

\subsection{Relationship between the Variables}

\subsubsection{Relationship between Logistic Management and Firm Performance.}

Table 5: Correlations analysis showing the relationship between logistic management and firm performance

\begin{tabular}{|ll|l|l|}
\hline & & $\begin{array}{l}\text { Logistic } \\
\text { Management }\end{array}$ & Firm Performance \\
\hline \multirow{2}{*}{ Logistic Management } & Pearson Correlation & 1 & $.986^{* *}$ \\
& Sig. (2-tailed) & & .000 \\
& $\mathrm{~N}$ & 122 & 122 \\
& Pearson Correlation & $.986^{* *}$ & 1 \\
Firm Performance & Sig. (2-tailed) & .000 & 122 \\
& $\mathrm{~N}$ & 122 & 122 \\
\hline
\end{tabular}

**. Correlation is significant at the 0.05 level (2-tailed).

From Table 5 above, it shows that the Pearson's Product Moment Correlation coefficient (r) is 0.986. This indicates a very strong positive relationship between logistics management and firm performance. This means that direct relationship exist between the two variables and further improvement in logistics management will result in the enhancement of performance of the firms studied. Furthermore, the Table also shows probability/significant value (PV) of 0.000 which is less than $(<) 0.05$ (level of significance). Indicating, there is significant relationship between logistics management and firm performance. 


\subsubsection{Relationship between Physical Distribution and Sales Growth}

Table 6: Correlations analysis showing the relationship between physical distribution and sales growth

\begin{tabular}{|ll|c|c|}
\hline & & $\begin{array}{c}\text { Physical } \\
\text { Distribution }\end{array}$ & Sales Growth \\
\hline \multirow{3}{*}{ Physical Distribution } & Pearson Correlation & 1 & $.816^{* *}$ \\
& Sig. (2-tailed) & & .000 \\
& N & 122 & 122 \\
Sales Growth & Pearson Correlation & $.816^{* *}$ & 1 \\
& Sig. (2-tailed) & .000 & 122 \\
\hline
\end{tabular}

**. Correlation is significant at the 0.05 level (2-tailed).

From Table 6 above, it shows that the Pearson's Product Moment Correlation coefficient (r) is 0.816. This indicates a very strong positive relationship between physical distribution and sales growth. This means that direct relationship exist between the two variables and further improvement in physical distribution will bring about increase in sales growth of the firms studied. Furthermore, the Table also shows probability/significant value (PV) of 0.000 which is less than (<) 0.05 (level of significance). Indicating, there is significant relationship between physical distribution and sales growth.

\subsubsection{Relationship between Physical Distribution and On-time Delivery}

Table 7: Correlations Analysis showing the relationship between physical distribution and on-time delivery

\begin{tabular}{|ll|l|l|}
\hline & & $\begin{array}{l}\text { Physical } \\
\text { Distribution }\end{array}$ & On Time Delivery \\
\hline \multirow{3}{*}{ Physical Distribution } & Pearson Correlation & 1 & $.929^{* *}$ \\
& Sig. (2-tailed) & & .000 \\
& $\mathrm{~N}$ & 122 & 122 \\
& Pearson Correlation & $.929^{* *}$ & 1 \\
On Time Delivery & Sig. (2-tailed) & .000 & 122 \\
& $\mathrm{~N}$ & 122 & \\
\hline
\end{tabular}

**. Correlation is significant at the 0.05 level (2-tailed).

From Table 7 above, it shows that the Pearson's Product Moment Correlation coefficient (r) is 0.929. This indicates a very strong positive relationship between physical distribution and on time delivery. This means that direct relationship exist between the two variables and further improvement in physical distribution will bring about better on time delivery of the firms studied. Furthermore, the Table also shows probability/significant value (PV) of 0.000 which is less than (<) 0.05 (level of significance). Indicating, there is significant relationship between physical distribution and on time deliver. 


\subsubsection{Relationship between Transportation and Sales Growth.}

Table 8: Correlations Analysis showing the relationship between transportation and sales growth

\begin{tabular}{|ll|l|l|}
\hline & & Transportation & Sales Growth \\
\hline \multirow{3}{*}{ Transportation } & Pearson Correlation & 1 & $.919^{* *}$ \\
& Sig. (2-tailed) & & .000 \\
& N & 122 & 122 \\
& Pearson Correlation & $.919^{* *}$ & 1 \\
Sales Growth & Sig. (2-tailed) & .000 & \\
& N & 122 & 122 \\
\hline
\end{tabular}

**. Correlation is significant at the 0.05 level (2-tailed).

From Table 8 above, it shows that the Pearson's Product Moment Correlation coefficient (r) is 0.919. This indicates a very strong positive relationship between transportation and sales growth. This means that direct relationship exist between the two variables and further improvement in transportation will result in higher sales growth of the firms studied. Furthermore, the Table also shows probability/significant value (PV) of 0.000 which is less than $(<) 0.05$ (level of significance). Indicating, there is significant relationship between transportation and sales growth.

\subsubsection{Relationship between Transportation and On-time Delivery}

Table 9: Correlations Analysis showing the relationship between transportation and on-time delivery

\begin{tabular}{|ll|l|l|}
\hline & & Transportation & On Time Delivery \\
\hline \multirow{3}{*}{ Transportation } & Pearson Correlation & 1 & $.960^{* *}$ \\
& Sig. (2-tailed) & & .000 \\
& $\mathrm{~N}$ & 122 & 122 \\
& Pearson Correlation & $.960^{* *}$ & 1 \\
On Time Delivery & Sig. (2-tailed) & .000 & \\
& $\mathrm{~N}$ & 122 & 122 \\
\hline
\end{tabular}

**. Correlation is significant at the 0.05 level (2-tailed).

From Table 9, it shows that the Pearson's Product Moment Correlation coefficient (r) is 0.960. This indicates a very strong positive relationship between transportation and on-time delivery. This means that direct relationship exist between the two variables and further improvement in transportation will bring about better on time delivery of the firms studied. Furthermore, the Table also shows probability/significant value (PV) of 0.000 which is less than $(<) 0.05$ (level of significance). Indicating, there is significant relationship between transportation and on-time delivery. 


\subsubsection{Effects of Logistic Management on Firm Performance.}

Table 10: Summary of regression analysis result showing the effects of logistic management on firm performance

\begin{tabular}{|c|c|c|c|c|c|c|c|c|c|}
\hline $\begin{array}{l}\text { Variable } \\
\text { s }\end{array}$ & Coef. & t-cal & sig. $\mathrm{t}$ & $\begin{array}{l}\text { t-tab } \\
(0.05, \\
120)\end{array}$ & $\mathrm{R}$ & $\mathrm{R}^{2}$ & F-cal & $\begin{array}{l}\text { F-tab } \\
(0.05, \\
1,121)\end{array}$ & $\operatorname{sig} \mathrm{f}$ \\
\hline Constant & 2.114 & 4.048 & 0.000 & & & & & & \\
\hline $\begin{array}{l}\text { Logistic } \\
\text { Manage } \\
\text { ment }\end{array}$ & 0.963 & 65.239 & 0.000 & 1.96 & 0.986 & 0.973 & 4256.185 & 3.92 & 0.000 \\
\hline
\end{tabular}

Dependent Variable; Firm Performance

Source: Field survey, 2017

$$
\begin{array}{cc} 
& \mathrm{FP}=\mathrm{a}_{0}+\mathrm{a}_{1} \mathrm{LM}+\mathrm{U}_{1} \\
& \mathrm{FP}=2.114+0.963 \mathrm{LM} \\
\text { T-values } & =(4.048(65.239)
\end{array}
$$

Table 10 above reveals that the coefficient of correlation is 0.986 . This shows that significant and very strong relationship exists between logistics management and firms' performance because $r$ is closer to one (1). Also, the Coefficient of Determination $\left(\mathrm{R}^{2}\right)=0.973$. It implies that $97.3 \%$ variation in firm performance is explained by variations in logistics management. This implies that the above stated model has a good fit (explanation is $>50 \%$ ). Therefore the remaining $2.7 \%$ is explained by some other variables not covered in this study model. The F-calculated of 4256.185 had a corresponding significant t-value of 0.000 . Therefore, the researcher concludes that it is a good and useful model. Conventionally F-Cal $=4256.185>$ F-tab $(0.05,1,11)=3.92$ hence the decision of a useful model is upheld.

The test of significance conducted as shown in the table above shows that logistic management significantly influence firm performance $(\mathrm{PV}=0.000<0.05)$. More so, $\mathrm{t}-\mathrm{cal}=65.239>\mathrm{t}-\mathrm{tab}(0.05$, 121) $=1.96$

\subsection{7: Effects of Physical Distribution and Transportation on Sales Growth.}

\begin{tabular}{|c|c|c|c|c|c|c|c|c|c|}
\hline Variables & Coef. & t-cal & sig. $\mathrm{t}$ & $\begin{array}{l}\text { t-tab } \\
(0.05, \\
119)\end{array}$ & $\mathrm{R}$ & $\mathrm{R}^{2}$ & F-cal & $\begin{array}{l}\text { F-tab } \\
(0.05, \\
2,121)\end{array}$ & $\operatorname{sig} \mathrm{f}$ \\
\hline Constant & .719 & 1.145 & .000 & \multirow{3}{*}{1.96} & \multirow{3}{*}{0.931} & \multirow{3}{*}{0.866} & \multirow{3}{*}{384.939} & \multirow{3}{*}{3.07} & \multirow{3}{*}{0.000} \\
\hline $\begin{array}{l}\text { Physical } \\
\text { Distributi } \\
\text { on }\end{array}$ & .216 & 4.365 & .000 & & & & & & \\
\hline $\begin{array}{l}\text { Transport } \\
\text { ation }\end{array}$ & .736 & 13.323 & .000 & & & & & & \\
\hline
\end{tabular}

Table 11: Summary of regression analysis result showing the effects of physical distribution and transportation on sales growth

Dependent Variable; Sales Growth 


$\begin{array}{cc} & \mathrm{SG}=\mathrm{a}_{\mathrm{o}}+\mathrm{a}_{1} \mathrm{PD}+\mathrm{a}_{1} \mathrm{~T}+\mathrm{U} 1 \\ & \mathrm{SG}=0.719+0.216 \mathrm{PD}+0.736 \mathrm{~T} \\ \text { T-values } & =(1.145)(4.365)(13.323)\end{array}$

Table 11 above reveals that the coefficient of correlation is 0.931 . This shows that significant and very strong relationship exists between the dimension of logistics management and sales growth because $\mathrm{r}$ is closer to one (1). Also, the Coefficient of Determination $\left(\mathrm{R}^{2}\right)=0.866$. It implies that $86.6 \%$ variation in sales growth is explained by variations in physical distribution and transportation. This implies that the above stated model has a good fit (explanation is $>50 \%$ ). Therefore the remaining $13.4 \%$ is explained by some other variables not covered in this study model. The F-calculated of 384.939 had a corresponding significant t-value of 0.000 . Therefore, the researcher concludes that it is a good and useful model. Conventionally F-Cal $=384.939>$ F$\operatorname{tab}(0.05,1,111)=3.07$ hence the decision of a useful model is upheld.

4.2.7: Effects of Physical Distribution and Transportation on On-time Delivery.

Table 12: Summary of regression analysis result showing the effects of physical distribution and transportation on on-time delivery

\begin{tabular}{|c|c|c|c|c|c|c|c|c|c|}
\hline Variables & Coef. & t-cal & sig. $\mathrm{t}$ & $\begin{array}{l}\text { t-tab } \\
(0.05, \\
119)\end{array}$ & $\mathrm{R}$ & $\mathrm{R}^{2}$ & F-cal & $\begin{array}{l}\text { F-tab } \\
(0.05, \\
2,121)\end{array}$ & sig $\mathrm{f}$ \\
\hline Constant & .224 & .676 & .000 & \multirow{3}{*}{1.96} & \multirow{3}{*}{0.982} & \multirow{3}{*}{0.964} & \multirow{3}{*}{1586.735} & \multirow{3}{*}{3.07} & \multirow{3}{*}{0.000} \\
\hline $\begin{array}{l}\text { Physical } \\
\text { Distributi } \\
\text { on }\end{array}$ & .305 & 11.669 & .000 & & & & & & \\
\hline $\begin{array}{l}\text { Transport } \\
\text { ation }\end{array}$ & .714 & 25.512 & .000 & & & & & & \\
\hline
\end{tabular}

Dependent Variable; On-time Delivery

$\begin{array}{cc} & \mathrm{OTD}=\mathrm{a}_{\mathrm{o}}+\mathrm{a}_{1} \mathrm{PD}+\mathrm{a}_{1} \mathrm{~T}+\mathrm{U} 1 \\ \mathrm{OTD}=0.224+0.305 \mathrm{PD}+0.714 \mathrm{~T} & \\ \mathrm{~T} \text {-values } & =(0.676)(11.669)(25.512)\end{array}$

Table 12 above reveals that the coefficient of correlation is 0.982 . This shows that significant and very strong relationship exists between the dimension of logistics management and on time delivery because $r$ is closer to one (1). Also, the Coefficient of Determination $\left(R^{2}\right)=0.964$. It implies that $96.4 \%$ variation in on time delivery is explained by variations in physical distribution and transportation. This implies that the above stated model has a good fit (explanation is $>50 \%$ ). Therefore the remaining 5.6\% is explained by some other variables not covered in this study model. The F-calculated of 1586.735 had a corresponding significant t-value of 0.000 . Therefore, the researcher concludes that it is a good and useful model. Conventionally F-Cal $=1586.735>$ F$\operatorname{tab}(0.05,1,111)=3.07$ hence the decision of a useful model is upheld. 


\section{Summary of Decision on Test of Effects}

Table 13: Summary of result on regression Analysis (Test of Effects)

\begin{tabular}{|c|c|c|c|c|c|}
\hline & & & & Sig. $\quad$ Value/ & \\
\hline$s / n$ & Effects & $t-c a l$ & Direction & $\begin{array}{l}\text { Probability } \\
\text { Value }(P V)\end{array}$ & Conclusion \\
\hline 1 & $\begin{array}{llr}\text { Effects of } & & \text { logistic } \\
\text { management } & \text { on } & \text { firm } \\
\text { performance } & & \end{array}$ & 65.239 & $+v e$ & 0.000 & Significant \\
\hline 2 & $\begin{array}{l}\text { Effects of physical } \\
\text { distribution on sales growth }\end{array}$ & 4.365 & $+v e$ & .000 & Significant \\
\hline 3 & $\begin{array}{l}\text { Effects of transportation on } \\
\text { sales growth }\end{array}$ & 13.323 & $+v e$ & .000 & Significant \\
\hline 4 & $\begin{array}{l}\text { Effects of } \\
\begin{array}{l}\text { distribution on } \\
\text { delivery }\end{array}\end{array}$ & 11.669 & $+v e$ & .000 & Significant \\
\hline 5 & $\begin{array}{l}\text { Effects of transportation on } \\
\text { on-time delivery }\end{array}$ & 25.512 & $+v e$ & .000 & Significant \\
\hline
\end{tabular}

\subsection{Relationship between Logistic Management and Firm Performance.}

From Table 5 and Table 10, it was discovered that logistics management significantly and positively affect the performance of the firms studied. To further buttress the above relationship Gebresenbet and Bosona (2012) observed that in today's process driven organization, where the focus has shifted from functions to process, logistics has become an essential part of the process which affect the performance of the firms.

Furthermore, Ellinger, Daugherty and Keller (2000); Mentzer, Daniel, and Tomas (2001); Fugate, Mentzer, and Stank (2010), in their various studies empirically concluded that logistic management is a strategic vector in organizational performance in terms of service quality, effectiveness and overall profitability. Also, logistics management has a major role in enhancing the customers' satisfaction and their retention and thus creating a lifetime customer value which have the ability to affects the performance (Balakrishnan, 2009).

\subsection{Relationship between Physical Distribution and Sales Growth}

From Table 6 and Table 11, it was found that physical distribution affects sales growth positively and directly of the firms studied. In the same vein, Geraldine and Chikwendu (2013) opined that firms with great diversity of customers spread over vast geographical areas must integrate an effective system of distribution to achieve an acceptable customer service level in order to avoid reduction of market share. Also, Richard (1965) concluded that a highly responsive and reliable physical distribution system facilitates marketing efforts and actually help to generate additional sales volume for firms.

More so, it helps to minimize out-of-stock occurrences through more accurate inventory placement and control, hence, sales lost due to being out of stock will be minimized. This has an advantage 
of increasing the actual sales volumes, the level of customer satisfaction and the general market share of the firm (Chentnik, 2005). Hesket (2007) observed that efficient physical distribution enable firms to expand their market coverage in order to compete more profitably and more effectively in distant markets, or in markets that previously were marginal. In this way the company is enabled to expand its distribution, which in turn leads to increase sales growth.

\subsection{Relationship between Physical Distribution and On-time Delivery}

From Table 7 and Table 11, it was discovered that physical distribution significantly and positively affects the on-time delivery of the firms studied. More so, physical distribution that is well coordinated helps to meet supply deadlines that is order fulfillment and estimated demand can be efficiently satisfied that is when producing for an anonymous market (Domschke and Schield, 1994).

According to Bovee and Thill (2003) physical distribution is often one of the biggest influences on a firm's ability to successfully deliver products on time and it plays major roles in the performance of manufacturing firms. The development of more efficient physical distribution procedures frequently produces sufficient means for on time delivery of products. The importance of physical distribution is also based on its relevance to customer satisfaction, by storing goods in convenient locations for transporting to wholesalers and retailers, and by creating fast, reliable means of moving the goods to the consumers on time (Udeagha and Okeke, 1993).

\subsection{Relationship between Transportation and Sales Growth.}

From Table 8 and Table 12, it was discovered that transportation significantly and positively affect the sales growth of the firms studied. To further buttress the above relationship Yung-Yu, WenLong and Michael (2005) opined that transportation is the base of efficiency in logistics management and a good transport system brings benefits not only to service quality but also brings about sales growth in the firm. Day to day management decisions also relies on transport, as just in time methods for both production and distribution have become the standard. More so, with the growth in e-commerce, resulting in more and more home delivery of products, transportation costs have become very significant in firms' sales growth (Hesse and Rodrigue, 2000).

Transportation being one of the most visible elements in the logistics operations, has strong relationship on firm performance vis a vis the amount of sales it will make because products are usually not produced and consumed in the same location. Also, transportation programs that can deliver customers goods as at when required and in good condition, help to provide customer satisfaction and give a competitive edge to the firm (Cooper, Lambert, and Pagh, 2013).

\subsection{Relationship between Transportation and On-time Delivery}

From Table 9 and Table 12, it was discovered that transportation significantly and positively affects the on-time delivery of the firms studied. Furthermore, the role transportation plays in logistics system is more complex than carrying goods for the firm. By means of well-handled transport system, goods could be sent to the right place at right time in order to satisfy customers' demands. It brings efficacy, and also builds a bridge between producers and consumers and affects the delivery of a product (Yung-Yu et al, 2005). Without the linking of transportation, a powerful logistics strategy cannot bring its capacity into full play.

Geraldine and Chikwendu (2013) observed that continuous increase in the cost of transportation due to poor nature of roads, high cost of vehicles and spare parts poses a serious problem to an 
effective coverage of territories and on time delivery of firm's products. In other word, for firms to be able to meet up on time delivery, they should have an effective transportation system for easy movement of their products. Also, effective management of transportation helps a firm to increase its profitability through on time delivery of products to the consumers. More so, increasing the speed at which firms' delivers goods allows them to serve their customers better (Jack, 2006).

\section{CONCLUSION}

The objective of this work was to examine logistic management and firms' performance among selected firms in Rivers State, Nigeria and the findings of the study showed that logistic management has an influence on the performance of firms. More so, physical distribution and transportation has a very strong influence on sales growth and on time delivery respectively. Organizations that want to increase its performance must have a clear and vivid understanding of how logistic management works and manage it properly. Also, the environment in which firms operate changes so rapidly, it is therefore pertinent and important that organizations maintain their performance measurement system through proper and effective logistics management so that they can remain competitive in their various business environments.

\section{RECOMMENDATION}

Based from the findings of the study the following recommendations are made:

- Organizations should established and maintain standard and vanilla logistics management system, so that the right amount of stock is hold and economic order quantity is achieved through proper physical distribution of the product to achieve higher performance.

- Also, to attain reasonable on time delivery firms in general and managers in particular should be properly equipped with the newest technology in transportation.

- Logistics managers should try as much as possible to maximize space and enhance on time delivery to avoid delay to the distribution of products in order to meet customers demand through proper means of transportation.

- Cost minimization distribution and transportation mode should be selected in the keeping and allocation of products in other to meet up with on time delivery so that sales growth can be increased.

\section{REFERENCE}

Adedeji, Y. M. D. (2005). Outdoor space planning and landscape qualities of religious centre in Akure, Nigeria. Inter-World Journal of Science and Technology, 2 (1): 40-51.

Ahukannah, L.L., Ndinaechi, G.I., \& Arukwu, O.N. (2003). Commerce for Senior Secondary Schools. Onitsha: Africana-First Publishers Limited.

Balakrishnan, N. (2009). Handbook of the logistic distribution. Dekker: Marcel Inc.

Ballou, R. (1998). Business logistics management: planning, organizing and controlling the supply chain. New York: Prentice Hall.

Bamaiyi, H.H. (2011). An analysis of the problems associated with interregional movements of agricultural commodities from Zaria. Unpublished Msc Thesis, Dept. of Geography, Ahmadu Bello University, Zaria 
Banon, A. R., Aragon \& Sanchez, A. (2002). Explanatory factors of success competitive. An empirical study on the SMEs. Management magazine Notebooks, 1, 49-63

Bovee, C. L. \& Thill, J.V. (2003). Marketing. New York: McGraw Hill Inc.

Canci, E. (2003). Logistics management. Istanbul, UTIKAD.

Chentnik, C.G. (2005). Physical distribution management and its environment. International Journal of Physical Distribution and Logistics Management, 5 (1), 62-73.

Christopher, M. (2005). Logistics and supply chain management: creating value-adding network. UK: Prentice hall.

Cooper, M.C., Lambert, D.M. \& Pagh, J.D. (2013). Supply chain management: more than a new name for logistics. International Journal of Logistics Management, 8 (1), 57-69.

Domschke, W. \& Schild, B. (1994). Location decisions in distribution systems, in Issermann, H. (eds.): Logistic. Landsberg am Lech: Verlag Moderne Industry.

Ellinger, A.E., Daugherty, P.E. \& Keller, S.B. (2000). The relationship between marketing/logistics interdepartmental integration and performance in U.S. manufacturing Firms: an empirical study. Journal of Business Logistics, 21, 1-22.

Fair, M.L. \& Williams, E.W. (1981). Transportation and logistics. USA: Business Publication Inc. Fawcett, S.F. \& Cooper, M.B. (1998). Logistics performance measurement and customer successes. Industrial Marketing Management, 27, 341 - 357.

Flowmaster, (2010). Transportation and distribution systems. Retrieved from http://www.flowmaster.com/process_transportdistribution.html.

Fugate, B. S., Mentzer, J. T. \& Stank, T. P. (2010). Logistics performance: efficiency, effectiveness, and differentiation. Journal of Business Logistics, 31, 43-61.

Gebresenbet, G. \& Bosona, T. (2012). Logistics and supply chains in agriculture and food. Pathways to Supply Chain Excellence, 4, 125-146.

Geraldine, N. O. \& Chikwendu, D. U. (2013). Correlational analysis of distribution cost and freight characteristics of manufactured goods (case study of Unilever Nigeria plc). Journal of Logistics Management, 2 (1), 26-34. 
Griffith, G.E., Bryce, S., Omernik, J., Comstock, J., Rogers, A., Harrison, B., Hatch, S. \& Bezanson, D. (2004). Eco-regions of Texas (2 sided color poster with map, descriptive text, summary tables, and photographs). U.S. Geological Survey, Reston, Virginia.

Hesket, J. L. (2007). A missing link in physical distribution system. Journal of Marketing, 30 (4), 37- 41.

Hesse, M., \& Rodrigue, J.P. (2000). Evolution of logistical integration. Transport Geography 1 \& 2, $383-397$.

Jack, N. (2006). Distribution: the key to success overseas. Management Review, September, 4057.

Kasilingam, R. G. (1998). Logistics and transportation: design and planning. Massachusetts: Kluwer.

Kotler, P., \& Keller, K. L. (2006). Marketing management (12 ed.). Upper Seddle River: Prentice -Hall.

Lee, H. L. \& Amaral, J. (2002). Continuous and sustainable improvement through supply chain performance management. Stanford Global Supply Chain Management Forum, 1, 1-14.

Mason, R., \& Lalwani, C. (2004). Integrating transportation into the supply chain to improve supply chain performance. Proceedings of 9th Annual Logistics Research Network Conference, September - $370-378$.

Mattsson, L. G. (2004). Industrial marketing: the network perspective. Munich: Gabler Verlag.

Mentzer, J. T., Daniel, J. F., \& Huit, T. M. (2001). Logistic service quality as a segment customized process. Journal of Marketing, 65, 82-105.

Minner, S. (2001). Strategic safety stocks in reverse logistic supply chains. International Journal of Production Economics, 71, 417 - 428.

Minner, S. (2001). Strategic safety stocks in reverse logistic supply chains. International Journal of Production Economics, 71, 417 - 428.

Mohd, S. \& Yasuo, H. (2013). Sales growth, profitability and performance: empirical study of Japanese ICT industries with three Asean Countries. Proceedings of ASBBS, 20 (1), 81-98.

Musa, I. J. (2008). Intensification of urban agriculture as a strategy for poverty reduction in Zaria urban area. A paper presented at association of Nigerian geographers. Conference in Calabar, 25th-29th August. 
Nwokah, N. G. (2008). Strategic market orientation and business performance: European Journal of Marketing, 42, 279-286.

Richard, C. (1965). Physical distribution: key to improved volume and profits. Journal of Marketing, January, 42-61.

Rui, M. \& Luis, A. (2014). Logistics performance: a theoretical conceptual model for small and medium enterprises. JEL Classification: M10.

Stainer, A. (1997). Logistics- a productivity and performance perspective. Supply Chain Management 2 (2), 53-62

Stock, J. R. \& Lambert, D. M. (2001). Strategic logistics management (4th edi.). Boston: McGrawHill International Editions.

Stock, J. R., \& Lambert, D. M., (2001). Strategic logistics management (4th ed.). Boston: Irwin / McGraw-Hill.

Udeagha, A.O. \& Okeke, C.I. (1993). Principles of marketing. Enugu: New Generation Ventures Limited.

Yung-Yu, T., Wen- Long, Y., \& Michael, A. T. (2005). The role of transportation in logistics chain. Proceedings of the Eastern Asia Society for Transportation Studies, 5, 1657 - 1672. 